The extent to which Firm Size affects Stock Return in the

Israa Walied Hussein Kishk

\title{
The extent to which Firm Size affects Stock Return in the Egyptian Stock Market Israa Walied Hussein Kishk
}

\section{Abstract:}

This study aims to document how stock return is affected by firm size. This study uses mainly panel analysis technique of firms listed in EGX30 in the time period from 2010 to 2015. The findings showed that firm size is a significant factor in predicting average stock return in the Egyptian stock market. Unexpectedly, it was found that the return of the previous year (lag return) plays a major role in predicting stock return in the Egyptian stock market.

Toward this end, this study suggests that investors can rely on both size and the return of the previous year to predict future stock return.

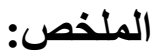

تهذف هذه الدراسة الى ايجاد محددات العائد في سوق الاور اق المالية

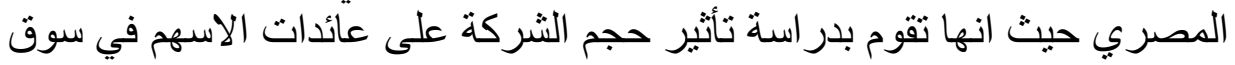

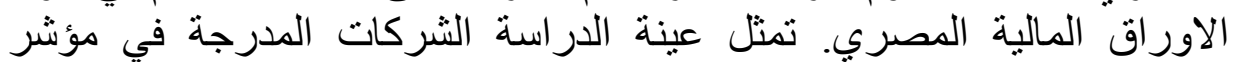

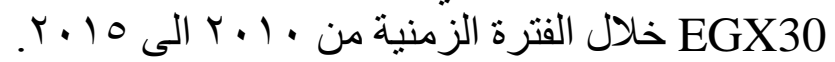

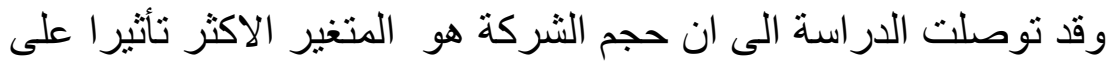

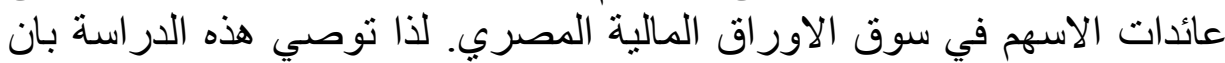

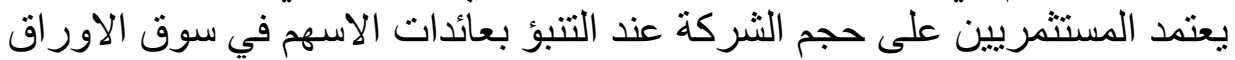

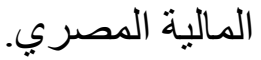


The extent to which Firm Size affects Stock Return in the

Israa Walied Hussein Kishk

\section{Introduction:}

The traditional microeconomic consumer theory suggests that a rational consumer makes his consumption decisions based on only two factors which are the price of the product and the consumer's income or wealth, but it did not take in consideration that consumers take decisions under risk. As a result, it can explain consumer behavior at non-financial markets well but when it comes to investors at financial markets, its hard to rely on the traditional microeconomic consumer theory given that investors make their decisions under a great amount of risk at financial markets. Consequently, researchers began to establish specialized theories that explain investment behavior.

The capital asset pricing model (CAPM) was the first to be developed by Sharpe (1964) and Linter (1965) which suggests that the rates of return on all risky assets are a function of their covariance with the market portfolio relative to the variance of the market. Although the capital asset pricing model is widely used among academics and practitioners, a growing number of researchers suggested that additional factors should be added in order to provide better explanation of average stock returns.

Rational asset pricing theory suggests that the predictive power of these variables comes from their ability to 
The extent to which Firm Size affects Stock Return in the

Israa Walied Hussein Kishk

capture information about time-varying risk which means that static CAPM failed to explain variations in average stock returns because it didn't take into account risk dynamics across stocks.

In 1992, Fama and French suggested that size provided better explanation than the CAPM. As a result, Fama and French (1993) developed a three-factor model which combines size, book-to-market equity and excess market portfolio returns. They proved that the model is successful in capturing the cross-section of average stock returns on U.S. stocks.

\section{Literature review:}

The size effect refers to the negative relation between security returns and the market value of the common equity of a firm (ME). It is calculated as a stock price multiplied by number of shares outstanding.

Size effect was firstly suggested by Banz (1981) who found that the CAPM is insufficient in explaining average stock returns and that there is a positive relationship between firm size and average stock returns. In other words, it was found that small firms (those with low market capitalization) have higher average returns than larger firms. In addition to 
The extent to which Firm Size affects Stock Return in the

Israa Walied Hussein Kishk

that, stocks of small firms have higher returns than what is predicted by their betas. Such relationship between firm size and average stock returns is known as the size effect. This evidence suggests that an additional variable (firm size) should be added to the beta in order to better explain average stock returns. However, Banz (1981) failed to provide evidence on the reason for considering size as a risk factor affecting stock returns.

In the light of Banz (1981) findings, Basu (1983) examined the size effect on US stock market and it was found that there is a significant relationship between firm size and average stock returns which confirms that beta alone is insufficient in expanding average stock return variation and that firm size should be taken in consideration when predicting future stock return.

The impact of firm size on stock return in the United Kingdom and Germany was examined by Drew et al. (2004) and found that small firms tend to have higher returns than large firms. They suggested that the reason is that small firms are more risky so high risk premium is compensation for the high risk.

Liew and Vassalou (2000) examined the effect of size and book-to-market equity in 10 countries. The findings 
The extent to which Firm Size affects Stock Return in the

Israa Walied Hussein Kishk

suggested that size and book-to-market equity have a great role in explaining average stock returns in developed countries. L'Her et al. (2004) found the same results in Canada. Similarly, Hawawini and Keim (2000) found evidence on the predictability of size and book-to-market equity in the US stock market and other several countries.

In Hong Kong stock market, the impact of both size and book-to-market equity ratio was examined by Lam (2002) and Nartea et al. (2008) and it was found that size and book-tomarket equity have superior predictability power as they were able to capture the cross-sectional variation in average monthly returns in Hong Kong stock market.

In Australia, Kassimatis (2008) compared between the ability of size and book-to-market equity and the ability of market beta and it was found that size and book-to-market equity provide better explanation for average stock returns when compared with the CAPM in the Australian stock market in a period from 1992 to 2005.

Tahir et al. (2013) examined the impact of book-tomarket equity ratio and firm size on stock return using 307 manufacture firms in Stock Exchange of Pakistan in a time period between 2000 and 2012. The results indicated that both 
The extent to which Firm Size affects Stock Return in the

Israa Walied Hussein Kishk

book-to-market equity ratio and firm size have a positive effect on stock returns of firms in Pakistan.

In the Egyptian stock market, the relationship between size and book-to-market equity ratio and average return in a time period from 2003 to 2007 was examined by Shaker and Elgiziry (2014a) and the results showed that there is negative relationship between both average stock return and size and average stock return and book-to-market equity ratio for small stocks.

Based on the evidence on the significance of size and book-to-market equity ratio in explaining average stock returns, Fama and French (1992) found that stock risks are not one-dimensional as suggested by the CAPM instead it is multidimensional and each dimension can be proxied by one risk factor such as size, book-to-market equity, leverage, earnings-per-price ratio.

Fama and French (1993) developed a three-factor model that combines the market risk (beta), size, and book-tomarket equity ratio and it was found that the model was successful in explaining average stock returns. 
The extent to which Firm Size affects Stock Return in the

Israa Walied Hussein Kishk

Iqbal and Brooks (2007) applied both CAPM and Fama-French three factor model in Pakistan's stock market and they found that

Fama and French three factor model out performed CAPM when using daily data, while both models failed to explain stock returns using weekly or monthly data.

When examining Fama and French three factor model in Korean stock market, Eom and Park (2008) found that the model had failed as it didn't explain variations in Korean stock return in a sufficient way.

Using stocks from 16 European markets, Bauer et al. (2010) examined the return predictability of Fama and French three-factor model. In other words, their goal was to examine whether the model has the ability to explain time variation and cross-sectional variation in returns and found that the model was unable to completely explain average stock returns as it failed to explain the momentum effect.

When examining the predictability power of both the capital asset pricing model and Fama and French three-factor model in 49 countries, Hou et al. (2011) found an evidence suggesting that the CAPM as well as Fama and French threefactor model are unable to explain variations in average stock 
The extent to which Firm Size affects Stock Return in the

Israa Walied Hussein Kishk

returns and that momentum and cash flow-to-price ratio were to capture variations in average stock returns in 49 countries in a time period from 1981 to 2003.

Lin et al. (2012) compared between the performance of beta and the performance of size and book-to-market equity ratio. It was found that size and book-to-market equity are significant when predicting portfolio returns. However, the market risk factor (beta) is the most appropriate when predicting individual stock returns.

Fama and French three factor model was applied in three emerging markets (Hong Kong, Singapore and Taiwan) by Shum and Tang (2005) and it was found that the model had succeeded as it is able to explain most of stock returns variations.

Avramov et. al. (2007) examined the role of conditional multifactor models and it was found that conditional multifactor models were successful in explaining size and value anomalies. However, they failed to explain momentum effects on returns in the US stock market.

Bundoo (2008) examined Fama and French three-factor model after taking in consideration the time variation in risk in Mauritius. 
The extent to which Firm Size affects Stock Return in the

Israa Walied Hussein Kishk

The evidence showed that Fama and French three-factor model is still robust even after taking into account the time variation in risk.

Lam et al. (2010) tested momentum-augmented Fama and French three factor model in Hong Kong stock market and the findings showed that the momentum-augmented Fama and French three factor model has the ability to explain variations in average stock returns.

Kim et al. (2012) compared between the performance of capital asset pricing model and Fama and French five factor model (liquidity and long-term reversal are added to FamaFrench three factor model). The findings showed that Fama and French five factor model was better than CAPM in explaining average stock return.

To conclude, Fama and French three factor model that combines market beta, firm size and book-to-market equity ratio was found to have higher predictability power than the capital asset pricing model, which means that size and bookto-market equity plays an important role in explaining variations in average stock return in several developed markets.

\section{Research methodology:-}

This study depends mainly on secondary data on both the theoretical and empirical phases. The study covers most of 
The extent to which Firm Size affects Stock Return in the

Israa Walied Hussein Kishk

the articles, journals, reports and periodicals that address asset pricing theories, in order to provide a satisfactory literature overview on the theory and evidences related to different variables affecting average stock return.

The study will be conducted in the Egyptian stock market in the period from January 2010 to December 2015.The population of this study is all companies listed in the Egyptian stock exchange from 2010-2015. The study uses a sample of 25 firms out of 30 stocks listed on EGX 30, the Index of the most 30 active stocks. The excluded firms were due to missing market data.

According to the research nature and collected data the researcher test variables affecting stock return using panel data analysis and F-test at a 5\% significance level with a type I error of $5 \%$, which is typical for social science research.

\section{Study Results:-}

\section{Table no 4-16: LNSIZE Estimation Model}

Dependent Variable: Y1

Method: Panel Least Squares

Date: 08/03/16 Time: 15:18

Sample: 20102015

Periods included: 6

Cross-sections included: 24

Total panel (balanced) observations: 144 
The extent to which Firm Size affects Stock Return in the

Israa Walied Hussein Kishk

\begin{tabular}{|c|c|c|c|c|}
\hline Variable & Coefficient & Std. Error & t-Statistic & Prob. \\
\hline LNSIZE & 0.311125 & 0.063788 & 4.877513 & 0.0000 \\
\hline $\mathbf{C}$ & -6.920406 & 1.403924 & -4.929331 & 0.0000 \\
\hline \multicolumn{5}{|c|}{ Effects Specification } \\
\hline \multicolumn{5}{|c|}{$\begin{array}{l}\text { Cross-section fixed (dummy variables) } \\
\text { Period fixed (dummy variables) }\end{array}$} \\
\hline R-squared & 0.575881 & \multicolumn{2}{|c|}{ Mean dependent var } & -0.073652 \\
\hline $\begin{array}{l}\text { Adjusted R- } \\
\text { squared }\end{array}$ & 0.467991 & \multicolumn{2}{|c|}{ S.D. dependent var } & 0.375281 \\
\hline $\begin{array}{l}\text { S.E. of } \\
\text { regression }\end{array}$ & 0.273726 & \multicolumn{2}{|c|}{ Akaike info criterion } & 0.429673 \\
\hline $\begin{array}{l}\text { Sum squared } \\
\text { resid }\end{array}$ & 8.541554 & \multicolumn{2}{|c|}{ Schwarz criterion } & 1.048384 \\
\hline Log likelihood & -0.936483 & \multirow{3}{*}{\multicolumn{2}{|c|}{$\begin{array}{l}\text { Hannan-Quinn criter. } \\
\text { Durbin-Watson stat }\end{array}$}} & 0.681083 \\
\hline F-statistic & 5.337669 & & & 2.591465 \\
\hline $\operatorname{Prob}($ F-statistic) & 0.000000 & & & \\
\hline
\end{tabular}

According to panel estimation model using least squares ad autoregressive errors (AR) it can be concluded that:

\section{Coefficient of determination (R2)}

The Independent Variable (LNSIZE) explains (57.6\%) from total variation of Return (Dependant variable). 
The extent to which Firm Size affects Stock Return in the

Israa Walied Hussein Kishk

\section{F test}

Since the value of "F test" is (5.337669) with significant at the (.001) level, then the researcher concludes that the LNSIZE have a considerable impact on the firm's return.

\section{3. $t$ test:}

The results show that LNSIZE is a significant variable in the model as it shows a significant level (0.0000) which is lower than (0.05).

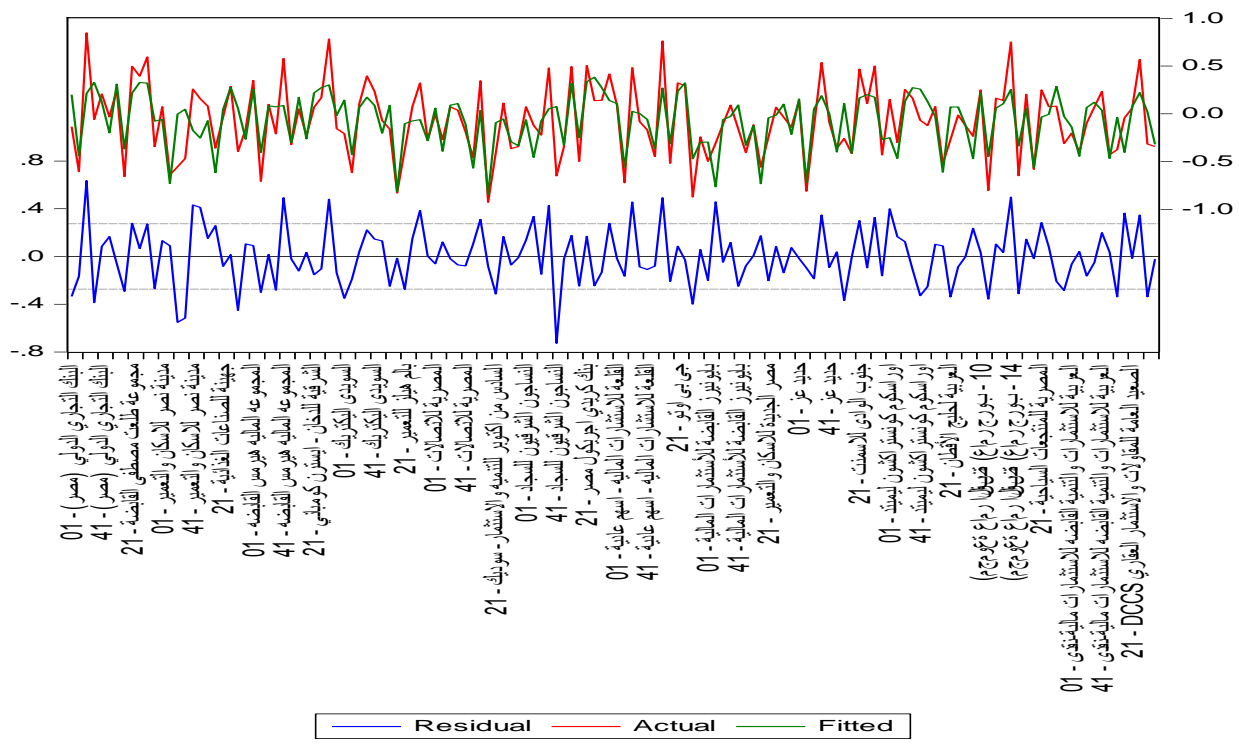

\section{Testing residuals normality (The Jarque-Bera Test)}

By examining the residuals, we found that it follows normal distribution as the significance level reached (.941448) 
The extent to which Firm Size affects Stock Return in the

Israa Walied Hussein Kishk

which is (>0.05), So H0 stating that the residuals follow normal distribution will be accepted. Therefore, we conclude that the observed distribution corresponds to or equal the theoretical distribution, i.e. the observed errors are normally distributed.

\section{Figure 4-3 Descriptive Statistics Residuals (Size)}

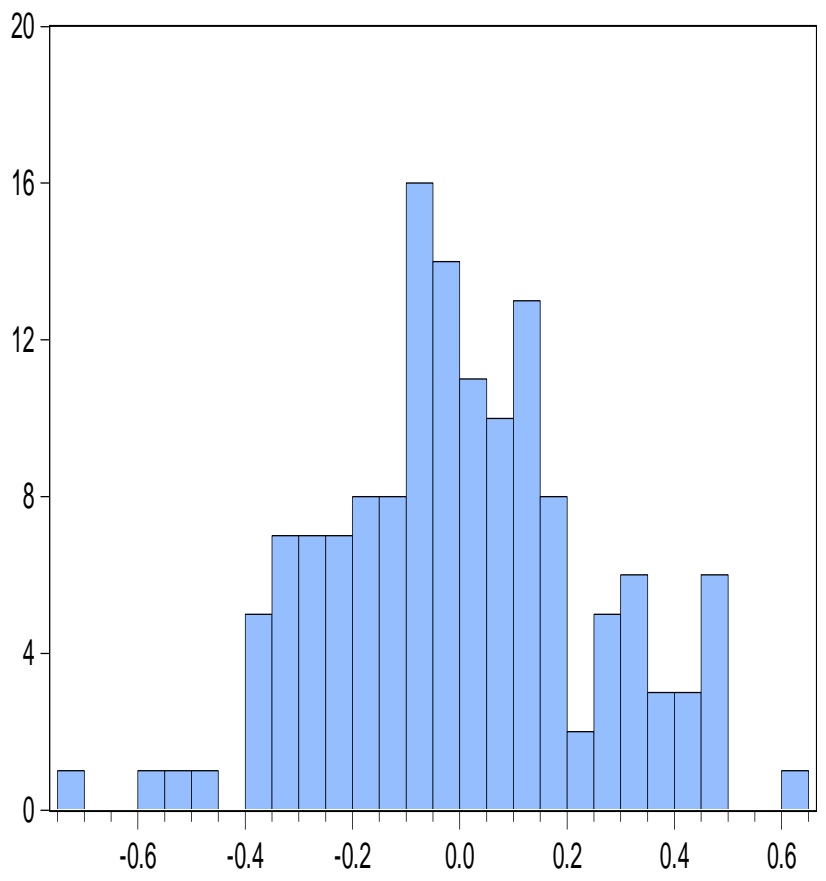

Series: Standardized Residuals

Sample 20102015

Observations 144

Mean $\quad 3.18 \mathrm{e}-18$

Median $\quad-0.014589$

Maximum $\quad 0.635126$

Minimum $\quad-0.726309$

Std. Dev. $\quad 0.244400$

Skewness $\quad 0.065664$

Kurtosis 2.946474

Jarque-Bera $\quad 0.120672$

Probability $\quad 0.941448$ 
The extent to which Firm Size affects Stock Return in the

Israa Walied Hussein Kishk

\section{Redundant Fixed Effects Tests}

\section{Table no 4-17: Redundant Fixed Effects Tests (LNSize)}

Test cross-section and period fixed effects

\begin{tabular}{cccc}
\hline \hline Effects Test & Statistic & d.f. & Prob. \\
\hline \hline Cross-section F & 1.556715 & $(23,114)$ & 0.0667 \\
Cross-section Chi- & 39.331048 & 23 & 0.0182 \\
square & & & 0.0000 \\
Period F & 12.311545 & $(5,114)$ & $\mathbf{0 . 0 0 0 0}$ \\
Period Chi-square & $\mathbf{6 2 . 1 7 4 8 0 0}$ & 5 & $\mathbf{0 . 0 0 0 0}$ \\
Cross-Section/Period F & $\mathbf{4 . 4 8 1 2 5 6}$ & $(28,114)$ & $\mathbf{0 . 0 0 0 0}$ \\
Cross-Section/Period & 106.884191 & 28 & \\
Chi-square & & &
\end{tabular}

The statistic values of Cross-section F" and "Crosssection Chi-square $(1.556715,39.331048)$ and the associated p-values strongly reject the null that the cross-section effects are redundant.

\section{Cross-section fixed effects test:}

Table no 4-18: Cross-section Fixed Effects Test Equation (LN

Dependent Variable: Y1

Method: Panel Least Squares

ملحتة العد دالرابي 17 
The extent to which Firm Size affects Stock Return in the

Israa Walied Hussein Kishk

Date: 08/03/16 Time: 15:19

Sample: 20102015

Periods included: 6

Cross-sections included: 24

Total panel (balanced) observations: 144

\begin{tabular}{|c|c|c|c|c|}
\hline Variable & $\begin{array}{c}\text { Coefficien } \\
\mathrm{t}\end{array}$ & Std. Error & t-Statistic & Prob. \\
\hline LNSIZE & 0.083361 & 0.024009 & 3.471995 & 0.0007 \\
\hline $\mathrm{C}$ & -1.908122 & 0.528900 & -3.607718 & 0.0004 \\
\hline \multicolumn{5}{|c|}{ Effects Specification } \\
\hline \multicolumn{5}{|c|}{ Period fixed (dummy variables) } \\
\hline R-squared & 0.442676 & \multicolumn{2}{|c|}{ Mean dependent var } & -0.073652 \\
\hline $\begin{array}{l}\text { Adjusted R- } \\
\text { squared }\end{array}$ & 0.418268 & \multicolumn{2}{|c|}{ S.D. dependent var } & 0.375281 \\
\hline $\begin{array}{l}\text { S.E. of } \\
\text { regression }\end{array}$ & 0.286232 & \multicolumn{2}{|c|}{ Akaike info criterion } & 0.383361 \\
\hline $\begin{array}{l}\text { Sum squared } \\
\text { resid }\end{array}$ & 11.22423 & \multicolumn{2}{|c|}{ Schwarz criterion } & 0.527727 \\
\hline Log likelihood & -20.60201 & \multirow{3}{*}{\multicolumn{2}{|c|}{$\begin{array}{l}\text { Hannan-Quinn criter. } \\
\text { Durbin-Watson stat }\end{array}$}} & 0.442023 \\
\hline F-statistic & 18.13626 & & & 2.287886 \\
\hline $\begin{array}{l}\operatorname{Prob}\left(\mathrm{F}_{-}\right. \\
\text {statistic })\end{array}$ & 0.000000 & & & \\
\hline
\end{tabular}

The previous table shows that LNSIZE in a significant independent variable in the Cross-section fixed effects test equation with significance level (0.0007) which is lower than 
The extent to which Firm Size affects Stock Return in the

Israa Walied Hussein Kishk

the error level (0.05). Since the value of "F test" is (18.13626) with significance level (.001), then the researcher concludes that LNSIZE have a considerable impact on the cross sectional level firm's return. Moreover, LNSIZE explains (44.3\%) from total variation of Return which is an average and acceptable explanatory power.

\section{Period fixed effects test:}

\section{Table no 4-19: Period fixed effects test equation (LNSize)}

Dependent Variable: Y1

Method: Panel Least Squares

Date: 08/03/16 Time: 15:19

Sample: 20102015

Periods included: 6

Cross-sections included: 24

Total panel (balanced) observations: 144

\begin{tabular}{ccccc}
\hline \hline Variable & Coefficient & Std. Error & t-Statistic & Prob. \\
\hline \hline LNSIZE & 0.417449 & 0.061470 & 6.791134 & 0.0000 \\
C & -9.260217 & 1.353013 & -6.844146 & 0.0000 \\
\hline \hline
\end{tabular}

Effects Specification

Cross-section fixed (dummy variables)

\begin{tabular}{cccc}
\hline \hline R-squared & 0.346865 & Mean dependent var & -0.073652
\end{tabular}


The extent to which Firm Size affects Stock Return in the

Israa Walied Hussein Kishk

$\begin{array}{cccc}\begin{array}{c}\text { Adjusted R- } \\ \text { squared }\end{array} & 0.215140 & \text { S.D. dependent var } & 0.375281 \\ \begin{array}{c}\text { S.E. of } \\ \text { regression }\end{array} & 0.332470 & \text { Akaike info criterion } & 0.791998 \\ \begin{array}{c}\text { Sum squared } \\ \text { resid }\end{array} & 13.15382 & \text { Schwarz criterion } & 1.307591 \\ \text { Log likelihood } & -32.02388 & \text { Hannan-Quinn criter. } & 1.001506 \\ \text { F-statistic } & 2.633257 & \text { Durbin-Watson stat } & 2.391600 \\ \text { Prob(F-statistic) } & 0.000300 & & \end{array}$

The previous table shows (LNSIZE) explains (34.7\%) from total variation of Return which is an acceptable explanatory power. It also shows that the value of "F test" is (2.633257) with significant at the (0.001) level, then the researcher concludes that the independent variable in the model have a considerable impact on the cross sectional level firm's return.

\section{Cross-section and period fixed effects test equation Table no 4-20: Cross-section and period fixed effects test equation (LNSize)}

Dependent Variable: Y1

Method: Panel Least Squares

Date: 08/03/16 Time: 15:19

Sample: 20102015

Periods included: 6

Cross-sections included: 24

Total panel (balanced) observations: 144

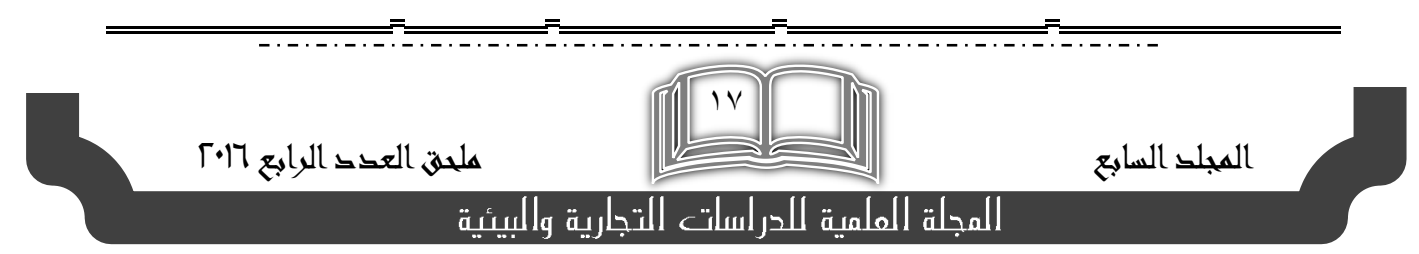




\section{جاممة قناة السوويس - كلية التجارة اللسماعيلية}

The extent to which Firm Size affects Stock Return in the

Israa Walied Hussein Kishk

\begin{tabular}{ccccc}
\hline Variable & Coefficient & Std. Error & t-Statistic & Prob. \\
\hline \hline LNSIZE & 0.119834 & 0.028741 & 4.169417 & 0.0001 \\
C & -2.710779 & 0.633186 & -4.281171 & 0.0000 \\
\hline \hline R-squared & 0.109070 & Mean dependent var & -0.073652 \\
Adjusted R- & 0.102796 & S.D. dependent var & 0.375281 \\
squared & & Akaike info criterion & 0.783036 \\
S.E. of regression & 0.355469 & Schwarz criterion & 0.824283 \\
Sum squared resid & 17.94290 & Hannan-Quinn criter. & 0.799796 \\
Log likelihood & -54.37858 & Durbin-Watson stat & 2.394001 \\
F-statistic & 17.38404 & & \\
Prob(F-statistic) & 0.000053 & & \\
\hline \hline
\end{tabular}

The previous table shows that the value of "F test" is (17.38404) with significance level (0.001), which means that LNSIZE have a considerable impact on the firm return. Moreover, the Independent Variable in the model (LNSIZE) explains (10.9\%) from total variation of Return. To conclude, the previous table shows that both sectors and time have significant effect on regression model equation.

\section{Residual Cross-Section Dependence Test \\ Table no 4-21: Residual Cross-Section Dependence Test (LNSize)}

Null hypothesis: No cross-section dependence (correlation) in residuals Equation: Untitled

Periods included: 6

Cross-sections included: 24 
The extent to which Firm Size affects Stock Return in the

Israa Walied Hussein Kishk

Total panel observations: 144

Cross-section effects were removed during estimation

\begin{tabular}{|c|c|c|c|}
\hline Test & Statistic & d.f. & Prob. \\
\hline Breusch-Pagan LM & 369.5714 & 276 & 0.0001 \\
\hline Pesaran scaled LM & 2.961156 & & 0.0031 \\
\hline $\begin{array}{c}\text { Bias-corrected scaled } \\
\text { LM }\end{array}$ & 0.561156 & & 0.5747 \\
\hline Pesaran CD & -1.683996 & & 0.0922 \\
\hline
\end{tabular}

According to the previous table, Pesaran CD and Biascorrected scaled LM tests are asymptotically standard normal, and due to the test statistic results we strongly accept the null at conventional levels i.e. there are No cross-section dependence (correlation) in residuals.

\section{Conclusion:-}

Predicting future stock return has attracted the attention of numerous researchers around the world for decades. Several variables have been examined and several models were proposed in an attempt to predict average stock return. However, till now there is no consensus among researchers on the relevant variables that explain average stock return in each market.

Fama and French (1993) presented a model that adds firm size and book to market equity ratio to stock beta in an 
The extent to which Firm Size affects Stock Return in the

Israa Walied Hussein Kishk

attempt to provide a model with a better explanatory power than the traditional capital asset pricing model. Fama and French presented evidence on the ability of their three factor model in predicting average stock return in the United States stock market.

Many researchers examined the ability of the new model in explaining variations in stock return in both developed and emerging markets and it was found that Fama and French three factor model plays a significant role in most markets.

The study sample consists of all firms listed in EGX 30 index excluding five firms due to data unavailability. Panel data regression was conducted on the sample firms. Furthermore, cross section fixed effect test and period fixed effects test were also conducted in order to examine the effect of the industry and time period on the return predictability.

Size was found to be the most significant factor affecting stock return as it was found that there is a significant positive relationship between size and stock return. Such result is consistent with Eraslan (2013), Taneja (2010) and Tahir et.al. (2013). However, it is inconsistent with Shaker and Elgiziry (2014) who examined the size effect in the Egyptian stock market in a time period 2003 to 2007. 
The extent to which Firm Size affects Stock Return in the

Israa Walied Hussein Kishk

In short, the main finding was that size plays a major role in explaining average stock return variation. It worth mentioning that the study unexpectedly revealed that there is negative relationship between the lag return (return of the previous year) and stock return. 
The extent to which Firm Size affects Stock Return in the

Israa Walied Hussein Kishk

\section{References:}

1. Amel-Zadeh, A., 2011. The return of the size anomaly: evidence from the German stock market. European Financial Management, Vol. 17, 2011, pp. 145-182.

2. Bartholdy, J. \&Peare, P., 2005. Estimation of expected return: CAPM vs. Fama and French. International Review of Financial Analysis, 14(4), pp.407-427.

3. Bundoo, S.K., 2008. An augmented Fama and French three-factor model: new evidence from an emerging stock market. Applied Economics Letters, pp.1213-1218.

4. Cakici, N., Fabozzi, F.J. \& Tan, S., 2013. Size value and momentum in emerging market stock returns. Emerging Markets Review, 16, pp. 46-65.

5. Djajadikerta, H., and Nartea, G., 2005.The size and book-to-market effects and the Fama-French three-factor model in small markets: preliminary findings from New Zealand. FIMARC working paper series, 0510, pp.1-17.

6. Fama, E.F. \& French, K.R., 2013. A Four-Factor Model for the Size, Value, and Profitability Patterns in Stock Returns. FamaMiller working Paper.

7. Gaunt, C., 2004, Size and book to market effects and the Fama French three factor asset pricing model: evidence from the Australian stock market. Accounting and finance, Vol. 44, pp.2744.

8. Horowitz, J.L., Loughran, T. \&Savin, N.., 2000. Three analyses of the firm size premium. Journal of Empirical Finance, 7(2), pp.143153.

ملثن العدى الرامي 17 
The extent to which Firm Size affects Stock Return in the

Israa Walied Hussein Kishk

9. Kassimatis, K., 2008. Size, Book to Market and Momentum Effects in the Australian Stock Market.Australian Journal of Management, 33(1), pp.145-168.

10. Lam, K.S.., 2002. The relationship between size, book-to-market equity ratio, earnings-price ratio, and return for the Hong Kong stock market.Global Finance Journal, 13(2), pp.163-179.

11. Liew, J. \&Vassalou, M., 2000. Can book-to-market, size and momentum be risk factors that predict economic growth?. Journal of financial economics 57, pp.221-245.

12. Nartea, G. V., Ward, B. D., \&Djajadikerta, H. G., 2009.Size, BM, and momentum effects and the robustness of the Fama-French threefactor model. International Journal of Managerial Finance, Vol.5(2), pp.179-200.

13. Nartea,G, Gan,C. and Wu, J., 2008. Persistence of size and value premia and the robustness of the Fama-French three-factor model in the Hong Kong stock market.Innovations and financial investment management, 5(4), pp.39-49.

14. Simlai, P., 2009. Stock returns, size, and book-to-market equity. Studies in Economics and Finance, vol.26 (3), pp.198-212. 